Миодраг Б. Лома*

Универзитет у Београду, Филолошки факултет

\title{
АЛЕКСАНДАР ИЛИЋ И СТРУКТУРАЛИЗАМ ЈАНА МУКАРЖОВСКОГ
}

Овим радом се приказује и вреднује критички поступак којим је Александар Илић (1945-2018), редовни професор на Катедри за Општу књижевност и теорију књижевности Филолошког факултета Универзитета у Београду - приступао развоју структуралистичке доктрине у делу Јана Мукаржовског (1891-1975), професора Карловог универзитета у Прагу. Илић је притом полазио са два комплементарна становишта, од којих је једно било критичка анализа којој је руски формализам и чешки структурализам подвргао Рене Велек (1903-1995), професор са Јејла и некадашњи члан Прашког лингвистичког круга, у коме је једну од главних улога имао Мукаржовски. Своје друго, допунско становиште за вредновање структуралистичке теорије и њене интерпретативне праксе у делу Мукаржовског преузима Илић из филозофских студија свог учитеља, претходника и потоњег колеге на истој београдској катедри Николе Милошевића (1929-2007), који је дошао до закључка да се у настајању једног књижевноуметничког дела мора утврдити јасна разлика између „услова“ и „узрока“. Наиме, по њему су и једни и други ванестетски чиниоци, при чему први доприносе целовитом уметничком обликовању функционално се подређујући естетичкој интенцији уметника, док јој се други супротстављају и ометају је, те разорно делују на уметничку конституцију дела. Тиме је Милошевић успео да разреши структуралистичку апорију узајамног односа естетских и ванестетских функција у једном уметничком делу. Милошевићеву „диференцијалну анализу“, која истанчано разликује упливе обликотворних од утицаја деформативних сила на настанак књижевноуметничког дела - могуће је овде допунити формално- и духовноисторијским разматрањима Паула Бекмана (1899-1987), професора на Универзитетима у Хајделбергу и Келну, који је уметничка уобличења посматрао као сасвим конкретне и значењски најпотпуније форме човековог схватања самога себе. Закључно се указује на перманентну структуралну дијалектику у мишљењу Мукаржовског као на дестабилизујући чинилац за темељно утврђивање текстуалног облика и његовог значења, односно естетског доживљаја и његовог тумачења.

Кључне речи: Александар Илић, Јан Мукаржовски, Рене Велек, Никола Милошевић, Паул Бекман; формализам, структурализам, филозофија диференције и диференцијална анализа, историја духа, историја форме, перманентна дијалектика, марксизам, деконструкција.

mloma@fil.bg.ac.rs 


\section{Увод}

Александар Илић је од средине седамдесетих година прошлог столећа био и остао до данашњих дана главни посредник и тумач идеја прашког структурализма не само у Србији, него и у читавој некадашњој Југославији, пре свега преко превода дела Јана Мукаржовског, али такође и кроз критичке уводе и коментаре бројним преведеним радовима чешких структуралиста. ${ }^{1}$ Систематизацију својих увида у развој руског формализма у чешки структурализам онако како се та еволуција одвијала у мишљењу Мукаржовског као најзначајнијег представника структуралистичког промишљања књижевности и уметности Илић је дао у монографији под насловом Од форме до структуре, Руски формализам / Чешки структурализам, посвећеној промени књижевнонаучне парадигме која се одигравала током тридесетих година двадесетог века као у том раздобљу једно од најважнијих и по својим главним дометима трајних постигнућа емпиријске филологије и на ову спекулативно ослоњене теорије књижевности, филозофије уметности и естетике. Управо таква достигнућа су утемељила Прашку књижевнотеоријску и естетичку школу, која ће свој светски значај постепено задобијати током друге половине двадесетог века добрим делом и преко радова њеног припадника, а потоњег наставника на Јејлу Ренеа Велека, чије је мишљење о чешком структурализму Илић веома уважавао и често узимао у обзир.

\section{О структурализму (1946) и његовом пореклу}

На почетку своје књиге која прати развој књижевнонаучне терминологије Од форме до структуре - Александар Илић меродавно указује на суштинску оријентацију новог приступа у истраживању поезије, наиме, на то да је „однос између звука и значења“ „био у средишту пажње структуралне теорије песничког језика“ (Ilić 2010: 8) коју је током тридесетих и четрдесетих година двадесетог века развио Јан Мукаржовски. „У предавању О структурализму, одржаном 1946. године у Словенском институту у Паризу“ овај чешки мислилац је порекло свог структуралистичког

1 Češki strukturalizam [zbirka prevedenih tekstova], Književna kritika, 3 (1975), Beograd: Rad; Mukaržovski, Jan: Struktura pesničkog jezika, 1986, Beograd: Zavod za izdavanje udžbenika; Mukaržovski, J.: Struktura, funkcija, znak, vrednost, Ogledi iz estetike i poetike, 1986, Beograd: Nolit; Vodička, Feliks: Problemi književne istorije, 1987, Beograd: Književna zajednica; Mukaržovski, J.: Studije iz estetike i poetike, 1998, Beograd: Zavod za izdavanje udžbenika. 
поступка везао како за домаће, тако и за стране подстицаје (исто). Њихов заједнички именитељ је сасвим извесно одвраћање погледа од живота писца, те усредсређивање на само дело, на његов језички облик и на значење тог уобличења, у чему су значајну улогу имали филозофски ставови потекли из хербартовског наслеђа и „неокантовске естетике“, затим Хусерлове феноменологије и Касирерове филозофије симболичких форми, али такође и лингвистичка схватања језичког феномена као споја гласовног знака са појмовним значењем код Фердинанда де Сосира и његових наследника у женевској школи, те „учења руских лингвиста“, а пре свега њихово „функционално разликовање песничког и комуникативног језика“ (исто: 10-11, 184-185).

Илић посебно истиче да у теорији књижевности и уметности чешки структуралисти, а нарочито Јан Мукаржовски као њихов „најистакнутији представник“ (исто: 20) - „прихватају, модификују и развијају схватања руских формалиста“ (исто: 11-12). Осим тога Илић скреће пажњу и на утицај нових, авангардних тенденција у уметности на чешке структуралисте, али такође и на њихов дијалог „са теоретичарима социолошке и марксистичке оријентације, као и са критичарима из редова традиционалних, грађанских интелектуалаца“ (исто: 12), дијалог који се заснивао на „Масариковом схватању друштвеног и културног живота као 'велике дискусије“, односно слободног „суочавања различитих научних, културних и уметничких тенденција“ (исто: 9), што је омогућавала демократска политика Масарикове државничке власти у раздобљу између два светска рата (исто: 184).

\section{Стилска критика и психологија поетских дела: Прилог естетици чешког стиха (1923)}

Илић је веома ценио мишљење Ренеа Велека о Прашкој школи књижевне теорије и естетике, зато што је овога видео као некога ко је својевремено био изнутра упућен у збивања у прашкој филологији двадесетих и тридесетих година двадесетог столећа. Наиме, Велек је у својој младости био близак Роману Јакобсону и Прашком лингвистичком кругу, чије је књижевнонаучно крило предводио Мукаржовски. Стога Илић уважава примедбу коју је Велек изнео 1970. године у чланку посвећеном „Књижевној теорији и естетици Прашке школе“ (The Literary Theory and Aesthetics of the Prague School) у другој књизи својих разматрања критичких појмова (Discriminations, Further Concepts 
of Criticism, 275-303²). Ту Велек примећује да је Мукаржовски на подстицај акустичких истраживања Зиверса и Зарана писао свој рад под насловом Прилог естетици чешког стиха, који је објављен 1923. године. У том монографском огледу Мукаржовски се бави „конкретном анализом одлика индивидуалног стила“ у „делима три истакнута чешка песника“ из друге половине деветнаестог века, Неруде, Чеха и Врхлицког. Илић увиђа да Мукаржовски ту ипак није испитивао само верзификацију, него такође и композицију и значења њихових песничких творевина (Ilić 2010: 6). Ако и даље следимо Велеково мишљење, овај пут оно које је изнето у његовој и Вореновој Теорији књижевности, која је по први пут објављена 1949. године, а у одељку под насловом „Еуфонија, ритам и метар“ (Euphony, Rhythm, and Metre) - Мукаржовски је тиме превазишао границе пуке акустичке анализе, која је иначе занемаривала значење, те изашао у сусрет поступку руских формалиста, који се поступно развијао ка холистичком приступу језичко-уметничком делу, при чему је повезивао његове звучне одлике са поретком и значењем његове целине (Wellek 1985: 169-173).

Илић указује на то да Мукаржовски у поменутом раду није анализирао само верзификацију она три песника, него и њихову психологију (исто: 46). Техничку анализу верзификационог стила усмерио је ка објективном утврђивању конкретних стилских обележја не само појединачних песничких дела као конструкција чврстог поретка, него и ка стилистичкој карактеризацији индивидуалног поетског поступка њихових песника (исто: 5455). Напокон је те особене стилске карактеристике повезивао са њиховим значењем у оквиру индивидуалне психологије уметника. Притом је изричито одбацио импресионистичку критику, „недостатке метафизичке, спекулативне естетике“ (исто: 6), њен „априоризам и нормативизам“, као и део позитивистичког критичког наслеђа, пре свега тумачење књижевних или уметничких дела као „механичких последица“ „ванкњижевних или вануметничких“ узрока, а задржао је каузално објашњење обележја индивидуалног стила на основу психологије уметничке личности (исто: 54).

2 Овај текст уз незнатне измене и осавремењавање саставни је део и 7. тома Велекове Историје модерне критике, 1750-1950, у коме је насловљен као: „Jan Mukařovský (1891-1975): The Literary Theory and Aesthetics of the Prague School“, pp. 411-425, in: A History of Modern Criticism 1750-1950, vol. 7: German, Russian, and Eastern European Criticism 1900-1950, New Haven and London: Yale University Press, 1991. 
Стилска критика и психологија прозног дела: Покушај стилистичке анализе
Бакице Б. Њемцове (1925)

По Илићевом мишљењу, и други рад Јана Мукаржовског, објављен 1925. године, под насловом Покушај стилистичке анализе Бакице Б. Њемцове - такође представља „мешавину формално-стилистичке анализе и психологизма“, још увек без непосредног уплива поступка руских формалиста (исто: 46). И овде се Мукаржовски позабавио једним значајним делом чешке књижевности деветнаестог века, али овај пут је то била проза у форми романа. Као и у Прилогу естетици чешког стиха, и у овој студији романескног стила, аутор је пошао од претпоставке да је „књижевне и уметничке вредности“ могуће свести на „психичке предиспозиције уметника“ (исто: 55, 57). Тако закључује да је „главна тајна стилистичког умећа“ Њемцове у пажљивом издвајању из стварности „малих детаља“, те њиховом једноставном, динамичном и хармоничном низању, чиме се производи „илузија саме суштине свеколиког збивања: бескрајног протицања, сталног долажења и одлажења, настајања и нестајања“. А то упућује на „саме корене“ књижевничиног бића, на „уравнотежену хармоничност њене природе“ и „њен оптимизам“, по којем су зло и смрт пролазни, односно смењиви „новим животом“ и „новом радошћу“ (исто: 55-56).

Утврдивши рано психологистичко становиште код Мукаржовског, Илић налази порекло таквога става управо у домаћој, чешкој филозофској традицији. Наиме, у раном развоју мисли Јана Мукаржовског овакав психологизам је „у највећој мери“ био преузет из „емоционалистичког схватања књижевности и уметности“ Отакара Зиха (исто: 56-57), наследника Отакара Хостинског, „првог професора естетике на чешком универзитету“ (исто: 21). Обојица су били „представници традиције неокантовске естетике“, тачније - главни заступници у Чешкој естетичких идеја из

наслеђа Кантовог следбеника Јохана Хербарта, које је дуго преовлађивало у чешкој теорији књижевности и уметности, као и у естетици, психологији и педагогији“ (исто: 10, 23).

Управо је Хостински обновио Хербартов „конкретни формализам“ (исто: 24). Илић констатује да је Зихов естетички емоционализам у „емоцијама уметника и примаоца уметничког дела видео естетске вредности, остављајући границу између психологије 
и естетике нејасном“ (исто: 56-57), те да се Мукаржовски надовезао на ову формалистичку традицију и на психологистички емоционализам Зиха, како би значење формалних одлика књижевноуметничког текста могао да тражи, па и да нађе у овоме најближем и најприснијем контексту, а то значи у оквиру психологије уметничког стваралаштва. Илић види јасно да је код Мукаржовског разоткривање „личности ствараоца“ преко индикација стицаних „техничком анализом“ - ово формално анализирање пунило значењем и повезивало га „са светом ванлитерарне и вануметничке стварности“ (исто: 57).

Александар Илић сасвим исправно сматра да је оваква психологија уметности у раним радовима Мукаржовског ипак попримала карактеристике „психологистичког каузализма“, који је „представљао последњи баласт прошлости“, то јест оптерећујући остатак наслеђа позитивистичке естетике деветнаестог века, њене каузалне механике и редукционизма (исто: 56). Тек схватање односа психологије уметника са психологијом уметничког дела, изложено у „радовима руских формалиста“ - растеретиће мисао Мукаржовског од позитивистичког терета, будући да су они релацију уметник-дело сагледавали динамички као сложену транспозицију „која објективизује уметничка значења и вредности“, чинећи их аутономним и независним од психологије уметничке личности (исто: 57-58).

\section{Прихватање формалистичког схватања \\ стиха: девијација, деформација и новина, аутоматизација и актуелизација (Примедбе уз Чешку прозодију Јозефа Крала, 1924)}

Илић нас обавештава да је Мукаржовски у чланку из 1924. под насловом „Примедбе уз Чешку прозодију Јозефа Крала“ (објављена у Прагу 1909. године) - прихватио

одређене теоријске ставове, део поетике руског формализма, које је у полемици са Краловим схватањем прозодије формулисао Роман Јакобсон у студији $O$ чешком стиху. (O českem stihe) (исто: 58,183 )

Овај рад је Јакобсон завршио још 1921. године (исто: 6-7), а објавио тек 1923. у Берлину на чешком језику (исто: 183). Наиме, Крал је „истицао како је за одређени језик погодна само једна прозодија“, једино таква која је „адекватна природи тог језика“, а у чешком она 
је искључиво „заснована на нагласку“ (исто: 58). Утолико је свака другачија за осуду, будући „девијација“ од прозодијске норме, односно „деформација песничког језика“. Баш у таквом деформисању Јакобсон је видео суштину сваке прозодије „као интенционалног раздвајања језика поезије од језика комуникације“. По њему, историја стиха је „смењивање различитих врста деформације“, како песнички учинак не би постао „аутоматизован“, већ како би „постизао естетско дејство ефектом новине“ (исто: 58-59). Управо кршење норме вануметничког језика прихватио је Мукаржовски у својим „Примедбама“ као основну развојну потенцију сваког прозодијског система, те је развој тих система схватио као „резултат унутрашњих сукоба песничких школа“, који се одвијају по „начелима аутоматизације и актуелизације“. Утолико се историја песништва показује аутономном, што слободно напушта вануметничке језичке праксе и у јасном изобличењу и различитости одступа од њих (исто: 59-60). Свакако да пука деформација устаљеног језика свакодневног општења не може бити никакво прозодијско мерило, већ, како је то Крал изнео - то мора да буде пре свега фонетска природа датог језичког медијума. Оспоравајући то становиште, формалисти, а за њима и Мукаржовски запостављали су објективна филолошка одређења и звучна ограничења сваког језика.

Мукаржовски је 1926. године објавио приказ књиге Романа Јакобсона Основе чешког стиха (Základy českého verše), која је исте године изашла у Прагу и у којој је Јакобсон сасвим јасно показао аналитичку свест формалиста о формативним, фонетским и фонолошким, прозодијским својствима одређених словенских језика, што у њеној темељној авангардистичкој тенденциозности ипак није значајно ограничило превасходну слободу новине као најзначајнијег чиниоца књижевноповесне динамике.

\section{Примена формалистичких схватања: естетска функција у Махином Мајy (1928)}

Нова, обимна студија Мукаржовског појавила се тек 1928. године под насловом Махин Мај. У њој је испитиван еп овог чешког романтичарског песника из прве половине деветнаестог века. Александар Илић утврђује да Мукаржовски ту „проницљиво примењује главне тезе руских формалиста“ (исто: 47). Пре свега следи њихово усредсређење на специфичне литерарно-естетске феномене, и то како на синхронијску статику, тако и на дијахронијску динамику ових појава, те на својствене законитости њихових 
узајамних односа. У предговору за своју студију о Махином спеву Мукаржовски јасно одређује своје методолошко полазиште. „Задатак естетичке анализе“ је да „у делу проучи она својства која изазивају његово естетско дејство“ (исто: 61). У циљу откривања естетских одлика књижевноуметничког дела - неопходно је „у средиште проучавања поставити само дело, као појаву sui generis, ослобођену од свих веза“ које је доводе у додир са „другим низовима појава, као што је, на пример, однос уметничког дела према ствараоцу или однос према спољашњој стварности која је представљала подстицај за дело“, или му је, евентуално, такође дала и тему (исто: 61-62). Мада ће Илић накнадно указати на естетистички и формалистички редукционизам овако заузетог становишта и на његове критичке последице (исто: 76-78), нужно је већ овде напоменути да чак и барем почетно усредсређење на испитивано дело никако не може представљати апсолутну естетичко-аналитичку редукцију на формалне естетске ефекте у његовом непосредном пријему, јер се оно увек прима као чинилац различитих савремених и повесних поредака из којих црпи своју обликотворну и смисаотворну моћ. Утолико је свако уметничко дело превасходно смисаодавно преобличење разноврсних облика затечених у датоме тренутку, као и оних који се од давнина наслеђују.

За Велека је Мукаржовски био не само зачетник структуралистичког погледа на естетске вредности књижевне уметности, него и главни репрезентант прворазвијеног структуралног приступа дотичним појавама. Основна начела тог поступка управо Велек усваја и заступа у „Уводу“ у „Унутрашње проучавање књижевности“, односно у „Четвртом делу“ своје и Воренове Теоpије књижевности (Velek/Voren 1974: 26, 170-171; Wellek/Warren 1985: 8, 140-141). Велек се ту ослања на тезе Мукаржовског које је овај изнео у уводном тексту за свој оглед о Махиној песми Maj. Изнете ставове Велек је углавном поновио у свом чланку о „Књижевној теорији и естетици Прашке школе“, одакле његово мишљење о структурализму Мукаржовског преноси Александар Илић (Илић 2010: 62-63). По Велеку, Мукаржовски у предговору својој монографији из 1928. године, која носи поднаслов Ecтетичка студија, у први план критичког истраживања ставља „естетску функцију“, чиме „уобичајено разликовање између форме и садржине постаје неодрживо“. Наиме,

ако сматрамо да слике, идеје и осећања представљају садржај, онда се језички елементи морају назвати формом. Но, ако тачније размотримо, морамо закључити да чак и елементи садржаја имају 
формални карактер: тако су, на пример, догађаји у неком епу делови садржаја, али начин на који су они распоређени у једној радњи био би део форме (Wellek 1970: 280).

Мукаржовски

прави разлику између елемената уметничког дела који су естетски индиферентни (које назива 'материјалом') и начина на који они постижу естетске учинке унутар једног уметничког дела (а који он назива 'формом'). У оквиру 'материјала' он разликује тему (слике, идеје и осећања) и језик, док је форма - организација тог материјала (Wellek 1970: 280-281).

Илић парафразом Велековог текста тумачи да Мукаржовски овде има на памети тематске „представе, мисли и осећања“ (Илић 2010: 68). Велек на истом месту тврди да Мукаржовски „у сагласности са руским формалистима“ „схвата уметничку форму у два њена главна обележја: деформације и организације“. Наиме, како је за Мукаржовског форма естетска организација иначе естетски индиферентног материјала, тако и деформација нема искључиво деструктивно значење, него поприма смисао уметничког преобличења и онеобичавања затеченог материјала, чиме се производи утисак новине (исто: 63). Овде се поставља питање језика као пуког „материјала“. Наиме, језик је увек извесно уобличење неке тематике, и то изворно не било какво, него са изразитом поетскоестетском тенденцијом. Уосталом, ниједна тема, ниједан мотив не постоје мимо њихове језички артикулационе форме. Утолико је посреди само преобличавање затечених језичких и песничких облика, што тек веома натегнуто може бити повезано са формалистичким појмом „деформације“.

По Илићевом налазу, у поменутом раду Мукаржовског је уметничко дело, готово мимо сваког значења и система вредности - посматрано искључиво као „скуп стилистичких метода“ којима се спречава аутоматизација његовог деловања у пријему публике (исто: 64). На тај начин и форма артефакта постаје за Мукаржовског „скуп обележја“ која „изазивају његово естетско дејство“ (исто: 67), односно специфична организација естетских карактеристика, коју је „најлакше проучити на самој употреби материјала, то јест језика и тематских елемената“ (исто: 68). Илић закључује да је Мукаржовски у студији о Махином Majy некритички преузео из раних формалистичких радова механицистичко и редукционистичко схватање књижевноуметничког дела као пуке „суме стилских поступака“ (исто: 76-77), односно апсолутизовање његове формалне димензије и „начела иманен- 
тног развоја књижевног низа, у којем спољашње интервенције не играју никакву улогу“. Из истих извора је чешки мислилац прихватио и „порицање референцијалних функција песничког дела“, те „успостављање поетике као дисциплине која проучава питања књижевности и уметности сасвим самостално, ослобођена свих веза са другим наукама“ (исто: 78).

\section{Појмови мултифункционалности и доминације: Тезе Прашког лингвистичког кружока и О савременој поетици (1929)}

Прашки лингвистички кружок основан је 1926. године (исто: 30), а своје Тезе је формулисао 1929. за Први конгрес словенских филолога у Прагу. Илић нам скреће пажњу да су Роман Јакобсон и Јан Мукаржовски саставили онај део тог документа који је био посвећен питањима језичко-уметничког израза (исто: 32) и у коме је наглашена разлика између „песничког и комуникативног језика“, али такође призната и могућност приближавања песничког - комуникативном изражавању као супротстављање затеченој језичкој традицији, уз закључно истицање непостојања „каузалних односа међу хетерогеним системима, те нужност испитивања песничког језика какав је он сам по себи“ (исто: 33).

Исте, 1929. године Мукаржовски „још опширније систематизује своје прихватање 'главних начела' формалистичког покрета“ у огледу О савременој поетици. Ту он одбацује еклектичку науку о књижевности која захтева да се књижевноуметничком делу истовремено приступа са много различитих гледишта, сходно његовој мултифункционалности. У таквом еклектицизму, примећује Илић, Мукаржовски сад сасвим јасно види преостатак „позитивистичког механицизма, каузализма и редукционизма социологистичке или психологистичке врсте“, који релативизује превласт естетске функције над свим другим у делу лепе књижевности. Наиме, естетска је за њега она функција без које дело не постоји као естетски феномен. Тако се само „естетичком анализом“ може доћи до његових суштинских естетских одлика, као и до правила њихове унутрашње повезаности. Такво анализирање утврђује управо естетску аутономију песничког дела као својствену веродостојност према посебним законитостима његове естетске функционалности, које се не поклапају са закономерношћу других, неуметничких функција (исто: 64-65). Но, притом не треба губити из вида да естетска функција својом апсолутном 
доминацијом у песничком делу себи подређује све његове друге хумане функције, а да њу саму формира управо начин на који конкретно овладава, преобликује и преосмишљава сваку другу функционалност, тако да свака од њих захваћена и преображена доминантном естетском формом сасвим конкретно учествује како у њеној изградњи, тако и у свом формалном преображају, те се никако не сме запоставити у свој својој конкретности као један од чинилаца уметничког преобличења.

Илић показује како је Мукаржовски сматрао да је ради чистоте и тачности естетичке аналитике неопходна методична изолација индивидуалног поетског феномена од свих осталих, ванестетских низова појава, те да се естетичка критика једног таквог дела код Мукаржовског показује као апсолутно иманентна, као она која објашњење свих естетских обележја дела налази искључиво у самоме делу (исто: 65-66). Александар Илић, с правом, закључује да Мукаржовски „заводи формалистички ембарго на повезивање форме и значења дела са ванлитерарном стварношћу“ и примећује да се тек из тог односа и преваге извесних ванестетских чинилаца могу схватити „слаба места“, то јест естетске девијације у самом артефакту. Илић тачно увиђа да је Мукаржовски желео да науку о књижевности учини апсолутно аутономном адекватно аутономији предмета њеног проучавања, да је ослободи по њу често штетног, редукционистичког уплива научног изучавања историје, социологије, психологије и других, пре свега хуманистичких дисциплина (исто: 66). При томе је, очигледно, Мукаржовски ипак отишао у супротну крајност - у радикалну специјализацију и феноменолошку изолацију ове хуманистичке науке која је својом дисциплином историје књижевности, онако како је ова оформљена у деветнаестом веку - претендовала да буде сумирајућа круна филолошких и хуманистичких научних истраживања, како на националном, тако и на универзалном плану.

Илић примећује да су се „формалне карактеристике“ уметничког дела указивале Мукаржовском као његове једине „битне одлике“, јер је увидео како се сви „елементи садржине“ претварају у елементе форме управо начином на који су уведени у један ексклузивно уметнички, обликотворни поредак, њиховим узајамним „спајањем у ланац [унутрашње] мотивације“. Утолико Мукаржовски долази до закључка да се свака „садржина управља према форми“, а да „форма себи изнуђује одговарајућу садржину“ (исто: 66-67), при томе заборављајући да је и са̂м нагласио узајамно одговарање облика и садржаја дела, при чему се ни један ни други чинилац при његовом схватању не могу занемарити. А 
још је Фридрих Шилер запазио како облик поништава изворни смисао коришћене садржине, тако што је преобличава сходно својој основној обликотворној замисли. Имајући на памети тај новоуобличени смисао - Шилер је у свом 22. писму о естетском васпитању човека тврдио да „форма уништава грађу“ („Darin also besteht das eigentliche Kunstgeheimnis des Meisters, dass er den Stoff durch die Form vertilgt“, Schiller 1955: 576). Ha основу запажања чешког филозофа Јозефа Зумра Илић зна да је естетички формализам у Шилеровом мишљењу о књижевности наслеђе естетике Имануела Канта и да је такво формалистичко промишљање естетског феномена преко Хербарта извршило пресудни утицај на чешку естетичку традицију, а посредством „руске формалне школе“ непосредно водило ка „чешкој структуралној естетици“ (исто: 24). Но само то смисаотворно преобличење књижевне грађе као поништавање њених изворних форми значења - подразумевало је аналитичко уважавање сасвим конкретне грађе баш онако како је она била традиционално уобличена и осмишљена, те као таква стављена на располагање уметнику. У Кантовом и Шилеровом филозофском речнику форма је увек уобличење смисла, а уметничка форма је производ сасвим конкретне слободне игре човековог нагона за смислом, за формалним осмишљењем сопственог постојања, и нагона за чулно непосредним поседовањем властитог света.

Илић указује на веома важну Теорију књижевности коју је Борис Томашевски објавио 1925. године и која је на пољу систематизације формалистичких знања о књижевној уметности представљала пионирско дело. Из ње Мукаржовски преузима и даље разрађује разликовање језика поезије од онога комуникације, који је економичан у изразу утолико што „тежи што јаснијем и лакшем преношењу мисли“, утолико што „води рачуна о томе шта се саопштава“, но не и томе „како се то чини“. „Песнички језик“, по Мукаржовском, „представља насиље“ над језичком комуникацијом, јер је својим „стилским фигурама“ „деформише“, те је тиме „онеобичава“ и естетски „актуелизује“, истичући у први план говорне перцепције „новину“ „начина на који се говори“, а која собом захваћене „језичке елементе“ ослобађа уобичајене комуникативне аутоматизације (исто: 68-69). Насупрот насумичности језичких девијација у емотивном или пак абнормалном говору, Мукаржовски „наглашава свесну систематичност и доследност деформације комуникативног језика у песничком делу“, па њене систематичне поступке идентификује као „средства обликовања“ (исто: 69), међу којима једно увек доминира, односно у њиховој хијерархији заузима позицију „доминанте“, што је, по 
Илићевом увиду, појам „преузет из текста Јурија Тињанова 'О литерарној еволуцији'“, објављеног 1929. године у књизи Архаисти и новатори (исто: 69-70).

Александар Илић објашњава да у литерарној аналитици Мукаржовског испитивању специфичне доминације неке од фигура деформације у „језичком материјалу“ следи истраживање деформативног начина на који мотивација доминира у тематском материјалу („мислима, осећањима, представама“). Мотивацијско деформисање и онеобичавање радњи објективне стварности производи нову стварност, ону књижевноуметничког дела, независну од било какве реалности ван ње, будући да се уметничка стварност повинује искључиво законитостима своје зачетне мотивационе идеје. Сваки мотив радње у артифицијелној реалности „само је припрема за оно што следи“, а тако уметнички повезан след мотива представља „мотивацију“, која закономерно прати једино своју стваралачку замисао, у чему је њена самосврховитост, те њен естетски учинак (исто: 70). Тако је поред поетског, чисто језичко-уметничког критеријума стилско-фигуралне доминанте уведено превасходно прозно мерило које се тиче мотивацијског низа, што је видљиво из признања Мукаржовског у његовом огледу $O$ савременој поетици да се, додуше, „понекад, на пример у роману, тематска конструкција дела може анализовати без обзира на језик“, док је „у многим случајевима, на пример у лирској поезији, тематска конструкција блиско повезана с језичким елементима“ (Mukaržovski 1986: 226), па је на тај начин непринципијелно враћен дуализам форме и садржине, у коју, свакако, спада сваки тематско-мотивски поредак. Наравно да је не само поезији него и прози, како би ова постала уметничка првенствено потребно естетско преобличење језика. А ову језичко-уметничку трансформацију она мотивацијска само прати на одговарајући начин, што Мукаржовски узима у обзир кад анализира Махин поетски $M a j$, те закључује да је „избор мотива, а самим тим и природа садржине дела, често предодређен формом“, односно неком доминантном језичком фигуром, јер тек таквом језичком формалном променом, таквим „преобликовањем садржина постаје законити део песничког дела“" (исто: 224-225).

Илић као репрезентативно наводи разматрање Мукаржовског, у коме овај наглашава да је циљ узајамно усаглашене, свесне и систематске деформације и онеобичавања језичког и тематског материјала управо у произвођењу јединствене и непоновљиве форме, формалне новине која се искључиво естетски може доживети као самој себи сврха. Такав доживљај одудара од осећања блаженства дефинисаног „естетичким хедонизмом“, будући да нас својом неуобичајеношћу пре свега „узнемирава и изазива“ 
(Ilić 2010: 71). А „књижевна еволуција“ се онда одвија кроз деформације, односно формалне иновације - „иманентно и аутономно“ као сукоб аутоматизације и актуелизације. Првим процесом се књижевноуметничко дело усваја и уобичајава у публици, постаје део традиције и својом формом даје канонизовану норму једној литерарној епохи. Други процес производи „узнемиравајућу“, антитрадиционалну и антиканонску новину. Та два супротстављена тока носе суседне генерације, при чему новина може бити „ослоњена на домашаје остварене у ранијим раздобљима, или у страним књижевностима, па и у другим слојевима књижевног збивања“, рецимо - у оним „нижим“ (исто: 71-72).

Илић примећује да Мукаржовски у огледу $O$ савременој поетици формом одређује књижевне родове и врсте, и то како са синхронијског „становишта статике“, тако и са дијахронијског „становишта динамике“ искључиво узајамних књижевних односа. Утолико се књижевна врста пре свега појављује као „устаљени скуп стваралачких средстава“, а њен развој се одвија исто као и укупна „еволуција књижевности“. Наиме, „употребом се троши група стваралачких средстава која чине врсту, аутоматизује се, губи естетско дејство и захтеву обнову“ (исто: 72-73). Илић закључује да се у тако схваћеном развоју књижевности као њена основна вредност појављује новина (исто: 80-81). Ипак, радикалним критеријумом иновације се сасвим дестабилизује скуп суштинских карактеристика књижевне врсте. Наиме, Мукаржовски тврди да се „током обнове може догодити да нестану оне ознаке жанра које су до тада биле доживљаване као суштинске, а да се очувају оне које су до тада биле споредне“, чиме се релативизује свака трајна дефиниција жанра. Он се, по мишљењу чешког аутора, може поуздано „дефинисати само у одређено доба, а никако као универзално важећа категорија“" (Mukaržovski 1986: 236).

Илић истиче да Мукаржовски у својим првим радовима, као што су студија о Махином Мају и оглед $O$ савременој поетици - некритички преузима ране формалистичке формулације (Ilić 2010: 74-75), мада су већ тада, 1928, у „свом програмском манифесту“ под насловом Проблеми проучавања језика и књижевности (исто: 77) Тињанов и Јакобсон настојали да превазиђу почетни „радикализам и једностраност“, односно „изолационизам“ „формалистичке поетике“. Њихова нова решења Мукаржовски ће прихватати са извесним закашњењем - каже Илић - као свако ко преузима туђе иновације (исто: 75).

Међутим, по Илићевој ваљаној процени, „одређене крајности у схаватањима раних формалиста“ „представљају трајан и непорецив допринос мисли о књижевности и уметности“, као што је оно „по којем је све у уметничком делу обликовано као естетско“, 
као што је „критика механистичког и каузалног извођења књижевних и уметничких дела из спољашњих околности“, затим „указивање на унутрашњу историју развоја књижевности и уметности на основу естетских изазова, на специфично естетску функцију језика уметничке књижевности“ (исто: 75-76). Илић такође увиђа да су учитељи Мукаржовског, руски формалисти у раној фази свог развоја занемаривали „емпиријски очигледну чињеницу да уметничко књижевно дело представља пре свега вишедимензионалну творевину и да синхронијско и дијахронијско проучавање књижевности и уметности није потпуно“, ако не узима у обзир њихову повезаност „са другим низовима појава“ (исто: 78).

Александар Илић нас упућује да управо Мукаржовски у огледу $O$ савременој поетици „сасвим изричито“ „указује на чињеницу да уметничко дело може имати више функција“, тако да она естетска „више није једина, већ доминантна“ и јасно разликује њене законитости од закона спољашње стварности, односно других духовних области, па му се „естетичка анализа“ и даље намеће као превасходна у испитивању књижевних појава. Али он се одриче анализирања значења књижевног дела ван његових граница, те указивања на везу између „текста и вантекстуалних реалности“ (исто: 79-80), то јест испитивања његове референцијалне функције. Утолико, по Илићевом тачном закључку, Мукаржовски подлеже новом „механицистичком каузализму“, који се сада заснива на иманентним релацијама у оквиру „књижевног развоја“" (исто: 81).

\section{Појмови мултивалентности и мултифункционалности: Песничко дело као скуп вредности (1932)}

У огледу из 1932. године под насловом Песничко дело као скуп вредности Мукаржовски посматра ове као „најразличитије“ „мноштво“ у коме естетска вредност ипак заузима „доминантан положај“, тако што се у преобличењу њоме појављују све друге (исто: 82). Илић добро схвата да се сада „однос естетских и ванестетских вредности“ у размишљањима Мукаржовског може разматрати како „са становишта функције“ ових других у „естетској конструкцији“ књижевноуметничког дела, тако и са становишта релације тих „вредности према лествици“ њима адекватних вредности ван самог артефакта (исто: 84), при чему чешки мислилац „очигледно разликује унутрашњу и спољашњу функционалност“, од којих прва има у најужем смислу „контекстуалну и естетску 
димензију, а друга референцијалну и ванестетску“. Александар Илић сматра да Мукаржовски управо таквим узајамним позиционирањем функција књижевноуметничког дела јасно почиње да заснива нове, структуралистичке ставове (исто: 85), допуштајући да испитивање „ванестетске функције“ књижевноуметничког дела „није проблем поетике, већ социологије песништва“, те да се извесно социолошко гледиште (исто: 86) не може искључити из „структуралне анализе“ уметничког текста, који се сада приказује као узајамни однос одређеног скупа вредности и њихових функција, од којих су неке активне и у социјалној пракси (исто: 87). Илић закључује да се на тај начин науци о књижевности дозвољава да проучава и „несумњиве везе“ песничког дела „са спољашњом реалношћу“ (исто: 88).

Било које друштвено или пак социолошки осмишљено и освешћено становиште може бити захваћено естетским поигравањем са различитим хуманим, индивидуалним и социјалним вредностима. А тек из те слободне уметничке игре, која није условљена ни индивидуалном психом аутора, ни њеном психологијом, као ни његовим социјалним статусом, па ни социологијом његове колективне припадности - настаје нов песнички облик којим се све затечене вредносне позиције преосмишљавају. Како бисмо спознали естетску генезу дела неопходно је упознати се са њеним полазиштима, са конкретним социјалним и индивидуалним хаосом хуманих вредности из којег она једнократно ствара свој уметнички поредак, своје уобличење космоса, свој непоновљиви песнички свет, а при томе социолошки, као и такође индивидуално-психолошки закључци увек остају пука хаотична грађа будуће поетске обликотворне и смисаотворне грађевине, тако да заостају за њом, те изостају из ње у свом претпесничком облику и значењу. Познавати њих даје књижевном критичару могућност да контрастивно закључује шта је песник оригинално начинио из расположивог материјала.

\section{Структура као носилац значења и корелација структура: Књижевни језик и песнички језик (1932) и Уз чешки превод Теорије прозе Виктора Шкловског (1934)}

У раду из исте, 1932. године Мукаржовски разматра Књижевни језик и песнички језик, наглашавајући њихову различитост, утолико што други посматра као естетски „интенционалну актуелизацију и деформацију“ првога, која занемарује саопштење, 
и „у први план ставља сам акт изражавања, говорења“ као самосврховит (исто: 88). Овде Јан Мукаржовски, по Илићевом сведочанству -

развија схватање структуре као сложене целине, отворене и динамичне, прожете дијалектичким односима слагања и неслагања, конвергенције и дивергенције, као творевине у којој постоје најразличитије вредности и функције, и коју уједињује доминација естетске вредности и функције над осталима, доминација која покреће и усмерава односе свих осталих компоненти и представља јединство sui generis, [...] означавано у естетици као 'јединство у разликама' (исто: 89-90).

Александар Илић нам поново скреће пажњу на значајно и прекретничко дело Тињанова и Јакобсона из 1928. године, на њихов оглед о Проблемима проучавања језика и књижевности, у коме су формулисали своје одступање од раног, радикалног формализма и приближавање ономе што ће ускоро постати структуралистичко становиште (исто: 95-96). Нов је њихов увид у повезаност „историје књижевности (односно уметности)“ „са другим историјским низовима“, као и у сложеност „иманентних“, „специфично структуралних законитости“ у свакоме низу, тако да закономерни „избор доминанте“ у једном уметничком делу постаје схватљив тек на основу „анализе односа литерарног низа и осталих историјских низова“. Ту „корелацију система“ називају аутори овог књижевнонаучног програма „системом система“, који такође има властите „структуралне законитости“. Ове идеје прихвата Мукаржовски 1934. године у приказу превода књиге Виктора Шкловског Теорија прозе $\left({ }^{1} 1925,{ }^{2} 1929\right)$ на чешки језик“ „и у студији Полакова Узвишеност природе“ (исто: 96-97). Илић примећује да је Мукаржовски у свом претходном раду већ користио појмове мултивалентности и мултифункционалности поетског дела, но недостајало је само њихово уједињење под појмом структуре (исто: 93).

Илић нас упућује да у раду насловљеном Уз чешки превод Теорuје прозе Виктора Шкловског Мукаржовски објашњава „формалистички радикализам“ приказиваног рада, по коме је „литерарно дело чиста форма, није ствар, ни материјал, већ однос материјала“ (исто: 10о) - потребом супротстављања дотадашњој радикалној редукцији књижевноуметничког дела на историјску (идеолошку и културну), социјалну и економску или пак биографску и психолошку садржину (исто: 98-99), како би се напокон оба крајња усмерења „дијалектички“ уравнотежила у програмски наговештеној „структуралистичкој синтези“ (исто: 100, 102-103, 104), у којој 
је и оно „формално“ „носилац значења“ (исто: 101), што су рани формалисти занемаривали (исто: 102). Илић вели да Мукаржовски овде „указује на сложен и повезан систем низова структура“, које имају функционалну аутономију, али које такође и узајамно функционишу, међу којима постоје и узајамни утицаји (исто: 103). А ови се „непрестано прегруписавају и узајамно усклађују“, чинећи тиме увек изнова извесну структуру узајамних функција (исто: 106-107) пре свега у значењској сфери (исто: 104) „тоталитета структура“ (исто: 106). Утолико се Мукаржовском са становишта „савременог структурализма“ „свака књижевна чињеница појављује“ „као резултанта двеју сила: унутрашње динамике структуре и спољашње интервенције“ (исто: 105). Притом „специфична функција било којег низа“ остаје неприкосновена као дата „његовом усмереношћу ка аутономији самог низа“. У случају песништва то је његова естетска функција (исто: 107). По Мукаржовском, ови структуралистички принципи истраживања важе у свим наукама (исто: 108). Вођен њима он посматра како се књижевноуметничко дело у својој „специфичности“ и „идентитету“ „повезује са другим низовима појава и сагледава као друштвени феномен“, као „естетски објект“ „У колективној свести“ (исто: 108-109).

\section{Примена новог структуралног метода у Полаковој Узвишености природе (1934)}

Александар Илић наводи да Мукаржовски овај „нови“, „структурални“ „метод проучавања књижевности“ примењује исте, 1934. у „анализи конкретног књижевног дела“, Полакове Узвишености природе из 1819. године (исто: 110). Тај оглед треба, сходно ауторовој намени, „да буде и пример структуралне књижевне историје, која схвата развој песништва као непрекинуто 'самокретање' (Selbstbewegung)“, но ипак у додиру са „другим појавама социјалног карактера“, као што су „идеологија, политика, економија, наука и тако даље“. Опсежна студија Мукаржовског о Полаковој поеми - по Илићевом увиду - подробно показује „како су се у њеном настанку ујединили унутрашња законитост развоја књижевног низа са спољашњим утицајима“ (исто: 111). Наиме, Мукаржовски каже да се „Полак трудио да створи 'високу' и ексклузивну лирику, која је требало да освоји за националну идеју 'високе' друштвене слојеве“. А „дескриптивна поезија“ је обележјима своје врсте омогућила стварање једног таквог дела. Тиме се „објашњава преузимање ове песничке врсте из страних литература“ (исто: 112). 
Илић сматра да је управо анализом Полакове поеме Мукаржовски „коначно и конкретно“ превазишао формализам, односно не само формулисао, него и кроз критичку праксу осведочио структуралистички приступ књижевноуметничком делу, који обједињује критички, историјски, теоријски и естетички поступак (исто: 112-113). Тим путем је показао како су „стилска обележја“ испитиваног песничког дела исход песниковог односа „према претходној књижевној традицији“ и „очекивања нових“ „слојева високог чешког друштва да добије поезију равну у високом стилу европској поезији тог доба“. Притом је чешки мислилац узимао у обзир и разматрао како „унутрашњу мотивацију“ дела (повезаност свих његових чинилаца), тако и његову „спољашњу мотивацију“ (повезаност са „другим низовима појава“) (исто: 113). По речима Мукаржовског, „последица подстицаја који је дошао споља“ - „представља резултанту двоструке силе“, утолико што се „свака интервенција једног низа у други остварује тек посредством иманентног развоја самог погођеног низа“ (исто: 114). У том смислу „историја књижевности се пита како је дело настало“, а „социологија књижевности“ - на који начин оно делује на друге социјалне низове (исто: 115). „Историја књижевности“ може успоставити „повезану развојну линију“, само ако узме „за њену основу ону функцију која је специфична за песништво као уметност, јер она једина ствара“ непрекидни развој, „док се остале остварују тек на њеној основи, иако у датом тренутку развоја нека од њих може“ „да преовлађује над естетском функцијом“ (исто: 115-116). Илић сведочи да је Мукаржовски преко „анализе лексичког материјала (посебно неологизама), стиха (метрике), тропа и фигура, мелодије“ и других стилских обележја - показао „како се у Полаковој поеми уједињују законитости унутрашњег развоја са спољашњим интервенцијама“. По суду Мукаржовског, Полакова песничка појава претходи „развоју новочешке поезије“, јер овај песник није био у стању да „радикално“ реконструише, те обнови „систем“ чешког стиха (исто: 116). Утолико само нова језичко-уметничка форма, односно структура - може изразити неко ново значење.

\section{Функционална дијалектика аутономног и комуникативног знака: Уметничко дело као семиолошка чињеница (1936)}

У огледу Уметничко дело као семиолошка чињеница, „који је прочитао на Међународном филозофском конгресу у Прагу 1934“, а 1936. године „објавио на француском у Актима конгреса“, Мукаржовски преузима појам и термин „семиологије“ 
из радова Фердинанда де Сосира (исто: 143), како би „разрешио антиномију аутономије и комуникативности песничког језика“ (исто: 144). Мукаржовски поетском језичком дискурсу и даље одриче „документарност“ као непосредно сведочење о стварности, али му признаје способност да „посредно“ сведочи о њој. Он сада увиђа да, „поред функције аутономног знака“ - „читава структура уметничког дела“ „функционише“ и као „комуникативни или информативни знак“, чије значење се кристалише, појашњава и разабира кроз „сиже дела“ као „осу“ једне такве уметничке „кристализације“. Пре свега „уметности сижеа“, као што су романескна и новелистичка проза - карактерише „дијалектичка антиномија између функције аутономног и функције комуникативног знака“ (исто: 145). Мукаржовски закључује да би без наведеног семиолошког разликовања било немогуће спознати „динамизам уметничке структуре“ и „схватити развој уметности као иманентно кретање, које је, међутим, у сталном дијалектичком односу према развоју осталих области културе“ (исто: 146). Но сиже као оригинална композиција тема и мотива у неком језичко-уметничком делу не сме се оцењивати као пука мотивација, него увек мора бити процењен искључиво са свог композиционог становишта које потенцира сасвим одређену фигуралну и формативну моћ датог уметничког језика, зато што је са̂м сижејни поредак увек компонован и уобличен неким језичким стваралачким, обликотворним средством, које тек сасвим непосредно даје коначно значење дотичној поетској појави.

\section{Мукаржовски и марксизам: естетска вредност као динамична целовитост узајамних односа ванестетских вредности (Естетска функција, норма и вредност као социјалне чињенцце, 1936)}

У својим радовима из друге половине тридесетих година двадесетог века, запажа Александар Илић - почиње Мукаржовски под утицајем марксистичких примедби да се бави питањима Естетске функције, норме и вредности као социјалним чињеницзама, како то тематски сажима у наслову свог огледа из 1936. године (исто: 16, 17-18). Критике чешких марксиста које су долазиле са позиција ортодоксног дијалектичког материјализма - по Илићевој оцени - само су „посредно утицале на Мукаржовског“, утолико што су му скретале пажњу на потребу да се „књижевност и уметност“ разјасне такође „и са друштвеног, идеолошког и 
политичког становишта“ (исто: 121). Марксистичке критике које су уважавале специфичност, „естетску самосвојност књижевности и уметности“, првенство естетског вредновања над оним са ванестетских полазишта - извршиле су непосредан утицај на књижевнотеоријску мисао Мукаржовског. Нарочито је Вашар уметности (Jarmark umění, 1936) Карела Тајгеа утицао на одређено теоријско позиционирање Мукаржовског у разматрањима узајамне повезаности естетских и социјалних чињеница (исто: 122).

На студију Мукаржовског о Књижевном... и песничком језику, објављену 1932. године у зборнику-манифесту чешких структуралиста под насловом Чешки књижевни језик и језичка култура - непосредно је критички реаговао са становишта марксистичке ортодоксије Бедржих Вацлавек у часопису Леви фронт (Levá fronta). Он прихвата руско формалистичко схватање песничког језика као „интенционалне естетске деформације“ књижевног језика, али одбацује „закључак Мукаржовског“ да је „суштина песничког језика у доследном потискивању комуникативне језичке функције“, те да је „тему уметничког дела могуће оцењивати једино са становишта структуре самог дела“. Вацлавек позива на поштовање „мерила истинитости, то јест слагања између теме у песничком делу и објективне стварности“ (исто: 122-123). Александар Илић назива „опасним“ такав „захтев“ којим се подразумева да постоји само једна истина и да је све друго сводљиво на њу, што представља „идеолошку фикцију“ „ауторитарног и тоталитарног“ погледа на свет. Насупрот томе, „уметност и књижевност поседују властиту естетско-значењску истину, која тек посредно указује на могућност различитих истина о човеку и свету“ (исто: 123). Тиме Илић брани истинску слободу хумане, моралне и естетске, односно уметничке индивидуализације и персонализације, слободу за индивидуалну и персоналну егзистенцијалну истину, те за њено оригинално етичко и артистичко формирање, за човеков истинити, увек особени и лични доживљај самога себе и света, људске заједнице и земаљске околине, као и за непоновљиво естетско уобличење властитог унутрашњег и спољашњег света. Без уважавања такве увек нове хумане истине нема поштовања ни личне, ни уметничке слободе, што је Илић и сам искусио живећи у комунистичкој Југославији.

Такође је и Курт Конрад у свом чланку Конфликт садржине и форме из 1934. године, као и Вацлавек - „бранио доминацију садржине над формом“, те замерао Мукаржовском што „одваја књижевну чињеницу од активности човека као класно одређеног друштвеног бића“ (исто: 124). Конрад је сходно марксистичком класном редукционизму и његовом насиљу над аутономијом 
различитих низова људских испољавања настојао да мерила класне свести наметне свеколикој људској пракси (исто: 124-125). На тај начин је и он, као и Вацлавек - оспорио човекову индивидуалну и персоналну слободу од сваког колективног одређења.

Завиш Каландра се у чланку $О$ методу књижевне историје 1934. осврнуо на исте године објављену студију Јана Мукаржовског о Полаковој Узвишености природе, замеривши му да „запоставља проблем личности ствараоца“, „стварне индивидуе која реагује на услове класног света“ (исто: 125). Каландра схвата стваралачку персону као динамичан и „непредвидљив“ скуп безбројних, „сасвим специфичних својстава“, те сматра да ју је „могуће испитивати“ само „у законитостима“ њених „реакција“ на „конкретан“ друштвени „оквир“, који је одређен економски и класно (исто: 126). Илић напомиње да је овај „Каландрин чланак представљао подстицај за низ есеја Мукаржовског посвећених проблему личности уметника“ (исто: 127).

Карел Тајге 1936. године у свом Baшару уметности прихвата „од руских формалиста и чешких структуралиста“ прворазредни значај индивидуалне уметничке форме као увек „специфичног закона“ за „конструкцију дела“ уметности (исто: 130). Он тражи да „марксистичка критика“ постане „вредновање материјала, начина његове обраде“, односно форме, настале особеним поступком уметничког обрађивања. Тајге захтева да критичко посматрање са становишта марксизма буде и формално вредновање сходно функционалној закономерности форме. По њему је ради таквог приступа неопходно да марксистичка критика одбаци њој својствени социолошки редукционизам, као и онај психолошки, присутан у психоаналитичком разматрању уметничких дела (исто: 128-129).

Илић закључује да „критика формализма у делу Мукаржовског“ „представља синтезу аутокритике самих руских формалиста“ „са критикама изреченим са других теоријских становишта“, а пре свега оног марксистичког. Такође није оригиналан ни прелазак Мукаржовског на структуралистичка схватања, јер и у том погледу он прати „'саморазвој' руског формализма у структурализам“ (исто: 131). Но Александар Илић увек истиче трајан допринос и формалистичке, и структуралистичке школе „одбрани слободе стваралаштва“ (исто: 132).

У студији, објављеној 1936. године под насловом Ecmemска функција, нормаивредност као социјалнечињенице Мукаржовски је преиспитивао структуре које превасходно естетски факти граде у својој динамичној комуникацији са друштвом, конституишући 
се као доминантни, да би убрзо били детронизовани. Притом је развијао и систематизовао почетне „социолошке анализе“ руских формалиста, у овом случају Шкловског и Ејхенбаума (исто: 147148). Мукаржовски је пошао од чињенице да је сваки чинилац уметничког дела „носилац ванестетских вредности“, па се оно појављује, заправо, као њихов скуп (исто: 149), тако да „вредновање“ представља неопходност у схватању комуникативног значења „уметничког знака“. Наиме, артефакт својим свестраним деловањем захвата не само појединачне ствари, него и „стварност као целину“, па се тиме дотиче укупног вредносног става према реалности код примаоца уметничког дејства, те је он тај ко вреднује (исто: 148). При томе се „естетска вредност“ показује само као „збирни назив за динамичну целовитост“ „узајамних односа“ „ванестетских вредности“ (исто: 150). Неке од тако схваћених естетских вредности мењају се брзо, а неке споро. Илић примећује да Мукаржовски „релативизује постојање универзалних, вечитих естетских вредности“, при чему преовладава „авангардистичка, револуционарна неизвесност сталне промене“ (исто: 149).

Мукаржовски је био идејни сапутник авангарде, али то је значило прихватити делом и анархију и нихилизам радикалне левице, њеног схватања друштва, политике и уметности (исто: 150-151).

У том погледу је Карел Тајге утицао на Мукаржовског авангардистички промовишући уједно Конструктивизам и ликвидаuију уметности, оне затечене „грађанске“, а ослањајући се на Бакуњиново схватање „духа деструкције“ као „стваралачког духа“ (исто: 150-151).

Александар Илић запажа како се Мукаржовски најпре позабавио „делима чешких песника деветнаестог века“, а да ће му тек

утицај руских формалиста, као и појава модерних уметничких дела, праваца и манифеста у чешкој уметности скренути пажњу [...] и на теоријска питања модерне уметности (исто: 13).

Утолико чешки структурализам - као и руски формализам, на који се структуралистички приступ непосредно надовезује (Ilić 2010: 12) - „представља генерализацију уметничке праксе“ оних „праваца у модерној уметности“ који су истицали своју уметничку „специфичност и аутономност“, као и „,формалне' и естетске квалитете“ својих производа, а потискивали „вануметничке вредности и функције“, пре свега „комуникативну функцију“ у песништву, а „имитативну“ у сликарству, наглашавајући важност „поступака 'актуелизације' и 'деформације““, те „мерила 'новине““ (исто: 14-15). 


\section{Структура као динамично дијалектичко јединство смисла (Структурализам у естетици и у науции о књижевности, 1940; О структурализму, 1946)}

У свом раду из 1940. године под насловом Структурализам у естетици и у науци о књижевности Мукаржовски дефинише структуру као „јединство смисла“ у коме сваки његов чинилац значењски указује на то јединство и обрнуто, будући да су сви они функционално повезани како са том јединственом целином, тако и узајамно, но та повезаност је и динамична, тако да све те „функције и њихови узајамни односи подлежу непрестаним променама“ (исто: 161-162). У ствари, он овде структуру посматра као „нематеријалну“, „динамичку равнотежу сила представљених појединим компонентама“. Једне су конзервативне и „конвенционалне“, а друге су револуционарне. Управо та напетост тежи уравнотежењу (исто: 162-163). У предавању $O$ структурализму из 1946. године Мукаржовски „и даље наглашава динамички карактер структуре“ као „скупа компоненти чија се унутрашња равнотежа непрекидно нарушава и поново ствара и чије нам се јединство стога јавља као скуп дијалектичких супротности“. Тиме он такође истиче истрајност структуралног дијалектичког идентитета (исто: 163). „Целовит смисао дела“ - који од њега чини структуру чија је свака компонента смисаотворна (исто: 164) омогућава управо доминација специфичне естетске функције индивидуалног уметничког дела, односно њеног производа - форме и оног значења које ова носи (исто: 165).

\section{Форма као структура и естетски аутономан знак хумано свестраног и свеобухватног значења (Песничка реч и стварност, 1940; Значај естетике, 1942; Уметност, 1943)}

У поговору својим преводима чланака Мукаржовског, издатим под насловом Огледи из естетике и поетике - Илић посебну пажњу посвећује раду овог чешког мислиоца о релацији „Песничке речи и стварности“, који је објављен 1940. године. Ту Мукаржовски доказује своје теоријске поставке кроз конкретну анализу песама Томана (прва половина двадесетог века), Халека 
(друга половина деветнаестог) и Сове (последње деценије деветнаестог и прве двадесетог столећа). Код сва три песника посреди су песничке творевине „посвећене истој теми, доласку пролећа“, само што су „формално различито уобличене“, тако да изражавају „три значењски различите интерпретације исте теме“. Утолико се показује, по Илићевом закључку, да „уметност није само форма, него у исто време и одређена интерпретација стварности, схваћене у најширем значењу те речи“. Мукаржовски примећује да у сваком од ових случајева „песничка реч проговара о нечем суштинском у стварности уопште, а не само о оној појединачној стварности које се непосредно тиче“. Дакле, и у песничкој речи је „садржано саопштење“, али само уз одређење „начина на који човек прима и доживљава целокупну стварност и начина на који дела у односу на њу“. Тако формативни поступак код Мукаржовског производи, по Илићевој процени - структуру као естетски знак, чије је значење хумано свеобухватно. О томе сведочи тврђење чешког мислиоца у његовом есеју о „Значају естетике“ из 1942. године да „естетски знак указује на све стварности које је човек доживео и може да доживи, ка целом универзуму ствари и збивања“ (Илић 1998: 217).

Илић сматра да је Мукаржовски у свом чланку из 1943. под насловом „Уметност“ сасвим складно „ујединио формалистичке и структуралистичке исказе“, тако што је аутономију уметности поново извео из „доминације“ „естетске функције“, будући да она „чини од ствари или акта у којима се манифестује - аутономан знак“, односно „чист естетски знак“, тако да притом пажња „буде усредсређена на унутрашњу конструкцију самог знака“, те тиме „естетски знак и „јесте уметничко дело“. Такво естетско означавање „ослобађа људску откривачку способност од схематизујућег утицаја којим је спутава животна пракса“ (исто: 218) и

даје увек изнова човеку свест о томе да је мноштво активних ставова које може заузимати према стварности једнако неисцрпно као и вишестраност стварности (исто).

Утолико је

уметност вишефункционална и оријентише свог примаоца ка другом систему функција од оног на који је навикао; води га ка другом, до сада неискоришћеном начину посматрања стварности, ка другом до сад непостојећем поступању са њом (исто).

Предност уметности у односу на „животну праксу и науку“ у томе је што може да антиципира будућност (исто). 


\section{Јан Мукаржовски и Никола Милошевић: интенција као уметничка формативна намера која производи смисао (Мукаржовски: Интенционалност и неинтенционалност у уметности, 1943; Милошевић: Узрок и услов, 1976)}

Александар Илић је у чланку Мукаржовског из 1943. године под насловом „Интенционалност и неинтенционалност у уметности“ пронашао место са кога је Илићев учитељ Никола „Милошевић могао поћи у своју откривалачку анализу негативног дејства психолошких и идеолошких фактора“ на „унутрашњу логику“ књижевноуметничког дела, дакле - одакле је било могуће започети истраживање деструктивног дејства које битно умањује специфичну естетску вредност литерарног артефакта. Милошевићева „унутрашња логика“ је у поменутом раду Мукаржовског „значењско јединство“ сваког производа уметности засебно, односно таква логичност је његов „смисао“ који увек производи уметничка формативна намера, „интенција“ (Ilić 2010: 157). А у Милошевићевом концепту разорну улогу добија управо подсвест, која мимо свесних обликотворних и смисаотворних намера уметника које чине „унутрашњу логику“ дела - разара његову иманентну логичку структуру (Лома 2014, 143-144).

Из Милошевићевог чланка под насловом „Узрок и услов“, објављеног у београдској Књижевној критици 1976. године, Илић наводи тврђење да постоје многа књижевна дела која су толико подређена ванкњижевним

функцијама да то битно нарушава њихову унутрашњу логику, као и што има литерарних творевина делимично прилагођених извесним друштвеним функцијама, без штете по уметничку вредност (Ilić 2010: 153-154).

Александар Илић тврди да се Милошевић „радикално и продорно одваја од формалистичко-структуралистичке традиције“ управо наведеним схватањем да све ванкњижевне функције и вредности никако не умањују естетску вредност књижевноуметничког дела, уколико су прилагођене његовој „унутрашњој логици“, односно потчињене „доминацији“ његове „естетске функције“ (исто: 154). Илић посебно истиче да овај Милошевићев став конкретно образлаже полазиште за једну теорију књижевног вредновања, која је код Мукаржовског наговештена само у „апстрактној 
формулацији“, а код Велека је остала „недовољно образложена и објашњена“, да би се у Милошевићевој критичкој пракси комплексно и целовито конкретизовала кроз „испитивање значења и значаја вредности које се јављају у одређеном књижевном/уметничком делу“, као што су то оне „друштвене, психолошке, метафизичке“ и тако даље (исто: 154-155). Тако је Никола Милошевић

показао да ваља разликовати општу и повољну друштвену условљеност уметничких појава (која се може испитивати у сваком појединачном и посебном случају) од узрочног, негативног и тенденциозног дејства друштвено-идеолошких и психолошких чинилаца (исто: 133).

Илић замера Мукаржовском што не покушава да одговори на питање зашто Полак није успео да препороди чешко стихотворство, па теоријски одговор на питања сличних књижевноуметничких промашаја налази у поменутом Милошевићевом раду, у коме се „спољашњи утицаји (интервенције)“ деле на „услове“, подстицајне за комплексност и кохерентност књижевноуметничког дела, будући да се њихов „утицај“ „подређује естетској доминанти“, и на „узроке“ који представљају утицаје снажнијег дејства, „идеолошке“ или „психолошке“, који својом силином ремете уметничку „сложенос““ и „кохеренцију“, те производе у артефакту артистички „слаба места“ (исто: 117-118). Милошевић је у свом разликовању узрока од услова пошао од Тојнбијеве теорије изазова, „по којој прејаки и преслаби изазови доводе до рђавих одговора“, а само они примерени снази онога ко одговара - до успешних (исто: 118). Држећи се тих претпоставки, Илић покушава да одговори на питање Полаковог неуспеха: у случају овог чешког песника „друштвени изазов“ је „био прејак“, а „оскудна“ је била „залиха“ затечених „уметничких средстава у чешкој лирици“. Отуда у његовој поеми „насилни, громопуцателни, претерани неологизми“, „немоћ да се изврши одговарајућа ритмичка диференцијација стиха“ и „да се уобличи одиста висока, а не бомбастична поезија“, непримерена књижевним очекивањима „високог чешког грађанског друштва“ (исто: 120-121).

Излагање о естетичко-критичком поступку Мукаржовског, чија дела је читао, преводио и тумачио, те из њих учио од своје младости - завршава Илић подсећањем на допуну и довршење структуралистичког приступа у раду свог непосредног учитеља Николе Милошевића, кога је давно био упутио на радове чешког мислиоца (исто: 204). Милошевић је решио структуралистичке антиномије, тако што је „однос спољашњих чинилаца према унутрашњој логици књижевног дела“ довео у везу са вредновањем и 
тумачењем дела (исто: 174-175). Милошевићев критичарски метод је даље развијао и успешно примењивао Александар Илић у својим радовима (исто: 201).

\section{Структурализам, либерална демократија и марксистички тоталитаризам}

Од краја двадесетих до пред крај четрдесетих година двадесетог века, односно до 1948. године када почиње комунистичка цензура - резимира Илић -

чешки теоретичари језика и књижевности развијају и модификују, углавном на домаћем језичком и уметничком материјалу, схватања руских лингвиста и формалиста. У овом добу настаје и дело Јана Мукаржовског, које најречитије говори о односу чешке и руске науке: од апологије и апликације, преко критике и модификације руског формализма, до уобличавања самосвојне теорије структурализма и семиотике (исто: 34 ).

За време нацистичке окупације Чешке Мукаржовски је у Прагу објавио своја Поглавља из чешке поетике (1941) из којих је ондашња тоталитаристичка цензура одстранила само студију о „филозофу толеранције“ „Масарику као стилисти“, да би 1948. публиковао проширено издање ове књиге, које је укључивало и чланак о Масариковом стилу (исто: 35-36). Мукаржовски ће тек 1966. опет бити у прилици да објави једно своје структуралистички конципирано дело. Реч је о његовим Естетичким студијама (исто: 38), које ће се појавити након што се Мукаржовски готово две деценије придржавао догматског става дијалектичког материјализма и социјалистичког реализма који је официјелно наметнула комунистичка тоталитарна власт (исто: $34,37,41$ ).

Након војне интервенције Варшавског пакта, која се одвијала под совјетским вођством крајем лета 1968. године - сузбијене су либерално-реформистичке снаге у чехословачкој влади, те је поступно поново уведена марксистичка догматска цензура за структуралистичке радове (исто: 38-40, 41), који нису писани „у духу тенденција социјалистичког реализма“. Илић с правом утврђује да је то „крај вредновања, не само у књижевности и уметности, већ и у друштву у целини“, те да је тиме „угрожена култура и душа народа“. Такво „наопако вредновање“ је било „случај не само у Чехословачкој од 1948. до 1989. године“. „Уосталом, све се то догађало у свету окренутом наопако“ (исто: 178), закључује Илић и сведочи: 
Године 1948. Мукаржовски је имао 58 година. Од тада, па до краја свог живота, 1975. године (рођен је 1891) Мукаржовски неће готово ништа написати. Тачније, оно што је и написао и објавио, било је под морање и боље да није угледало светлост дана (исто: 171).

У ствари, претходни научни успон је омогућен Масариковим демократским либерализмом у међуратној Чехословачкој. „Судбина чешког структурализма, као и руског формализма, била је често одређивана дејством неповољних спољашњих прилика“, примећује Илић и „наглашава Масариков утицај - пример демократске политике у култури“, политике која представља основни предуслов „за слободан развој науке и уметности“ (исто: 184).

Структурализам Мукаржовског и његова модификација у радовима Николе Милошевића и Александра Илића израз су либералне идеологије коју су они делили са Масариком, идеологије која уважава сваку слободу човековог мисаоног и друштвеног живота само под једним условом: да њено упражњавање не угрожава било коју људску слободу другога. За разлику од Мукаржовског, за разлику од његовог присилног преумљења на историјско-материјалистичко доктринарство и његов агресивни тоталитаризам, професори Милошевић и Илић на Универзитету у Београду никада нису напустили своје либерално и демократски толерантно усмерење, те су и под притиском југословенског комунистичког режима истрајавали као узори слободног мишљења, којим је једино могуће досегнути и очувати сву разноврсност људске истинитости, доброте и лепоте (Лома 2019: 167-190).

\section{Дијалектичко поимање структуре код Мукаржовског и холистички приступ (Ка речнику појмова чехословачке теорије уметности, 1947)}

Приликом употребе појма „структура“ током друге половине двадесетог века често се запостављао смисао целине уобличења неког језичко-уметничког дела, будући да се притом углавном инсистирало на примарности структурирања овога као преслојавања кроз које настаје песничка целина, па се, сходно томе, такође истрајавало у критичком приступу као раслојавању кроз који се утврђују ти превасходни поступци који граде слојевиту и сложену поетску конструкцију. По мишљењу Мукаржовског, које је изнео у свом раду из 1947. године под насловом „Ка речнику појмова чехословачке теорије уметности“: 
појам структуре заснован је на унутрашњем уједињењу целине узајамним односима њених компоненти, и те не само позитивним односима подударности и слагања, већ и негативним односима супротности и противречности. [...] Односи међу компонентама, управо зато што су дијалектички, не могу да буду дедуковани из појма целине; целина према њима није prius већ posterius, а њихово утврђивање зато није ствар апстрактне спекулације, већ емпирије (исто: 169-170).

Илић сматра да је овом дефиницијом Мукаржовски „довршио теорију структурализма“, тако што ју је коначно сасвим јасно одвојио од холистичких схватања, те „дефинисао књижевно и уметничко дело као отворену структуру“, као „креацију која се не може свести на претходне, затворене, холистичке концепте“ (исто: 170). На истом месту Мукаржовски дијалектички поставља и одговара на питање „сталности у структури“ сводећи је на стални „скуп компоненти“ чије су пак „корелације“ „подложне сталним променама“, при чему се као „релативна сталност“ у тим узајамним односима манифестује епохална актуелизација уметничке структуре, а као „апсолутна сталност“ - „непроменљиви основни закони развитка“ (исто: 170-171), односно деформације и актуелизације. Тиме се никако не излази из дијалектичког вртлога и његове нестабилности, штавише - неухватљивости која измиче сваком уравнотеженом и сталоженом просуђивању, па тиме вредносно сасвим релативизује уметничко дело.

Управо такво дијалектичко виђење структуре излазило је у сусрет раслојавању језичко-уметничког дела у структурализму након Мукаржовског, као и постструктуралистичкој деконструктивној аналитици, која разграђује један органски целовит артефакт на његове наизглед опозитне компоненте ради засебног истраживања неке од њих у њеној узрочној вези са неким од ванлитерарних каузалних следова, чиме је књижевнонаучно испитивање поново враћено каузалистици позитивизма.

А у време Мукаржовскога је марксистички императив класне борбе налагао издвајање из поетског дела као највреднијих, те најдостојнијих засебног посматрања - његових социјалних чинилаца и за њих је тражио узроке у социјалној реалности, у чијим оквирима је дело настало. Баш на то, са литерарног становишта, некритичко скретање - Илић скреће пажњу, али га „оставља по страни“ у разматрању поменутог списа Мукаржовског („Ка речнику појмова чехословачке теорије уметности“) (исто: 169). Но Илић претходно напомиње да се чешки мислилац у својим радовима из 1947. и 1948. године приближавао ставовима „тада 
већ постепено наметаног“ „дијалектичког материјализма“ и „социјалистичког реализма“, који су „после 1948. године, односно комунистичког пуча у Чехословачкој, постали 'гвоздени закон историје'“, коме се Мукаржовски напокон морао повиновати (исто: 167), прихватајући идеолошку тенденциозност уметности (исто: 168), у овом случају - наводно првенствени значај социјално-реалистичке тенденције при процени уметничких творевина.

Покушај Мукаржовског да споји структуралистичка схватања са дијалектичко-материјалистичким редукцијом на социјалистички реализам сматра Илић, с правом - „оксиморонским“ (исто: 167,169 ), па закључује да се увек мора уважити „идентитет, аутономија и квалитет естетске структуре“, коју таквом чини превласт „естетске доминанте“, те у којој су захваљујући томе све унете, „најразличитије вредности“ - „естетски преобликоване“, тако да им је промењено изворно значење у смислу нове уметничке целине. Кроз спој естетичке са значењском анализом укида се, по Илићевом мишљењу, „методолошки одређена, али у суштини неодржива подела на спољашњи и унутрашњи приступ проучавању књижевности и уметности“ (исто: 176), какву срећемо и у Велековој и Вореновој Теорији књижевности.

Баш ради брисања те вештачке поделе у приступању уметничким делима неопходно је да дијалектичко прилажење форми као структури артефакта, које је унеколико прикладно само у разматрању генезе дела - ипак буде замењено холистичким приступом овоме као трајном органском уобличењу, чиме се апсолутизује вредност његове естетске целине и њеног целовитог значења као оригиналног организма. Наиме, језичко-уметнички поредак је поетски космос који органски, а не дијалектички функционише, јер су сви његови чиниоци у јединственој служби његовом постојању сједињени при уобличењу тог постојања у један целовит, складан, довршен и савршен облик духовног живота, односно смисла, у коме нема више никакве борбе супротности. Песничка органска форма (поетски организам или поетска егзистенцијална организација) унутар себе је јединствена, те је у односу на све друго изван ње - самодовољна. Она се може назвати унутрашњом само сходно својој егзистенцијално конкретној самодовољности, својој самозаконитости, осведоченој увек особеним органским јединством естетске функционалности свега онога што чини њену целовитост. Утолико сваки од тих чинилаца може бити естетички анализиран само с обзиром на његово уметничко стварање дотичног јединства, које је својствено 
у сваком оригиналном песничком делу, те доступно искључиво на интуитивни начин кроз утисак естетске целине. Тек рационална критичка дескрипција и елаборација ове импресије, односно реторичка експликација и аргументација критике засноване на утиску уметничке целовитости - води ка његовом све пунијем интерсубјективном освешћењу, преношењу и усвајању, што је циљ естетског образовања.

Ипак утисак функционално-формалног јединства и јединствености језичко-уметничког дела није могуће привести к свести на основу пуке математички диференцијалне аналитике као некакву структуру која се раслојава на засебно функционалне планове све до њихових више недељивих чинилаца, чији се узајамни односи могу статистички предочити. Само тим рашчлањавајућим привидом региструју се ове посебне структурално конститутивне равни као доступне некој засебној, готово аутономној анализи, било да је реч о такозваном унутрашњем или спољашњем приступу књижевноуметничком делу, онако како су они аналитички концептуално стратификовани у Велековој и Вореновој Теорији књижевности, што ствара еклектичку заблуду да се било која раван песничке творевине може засебно проучавати, те да се тек накнадно исходи свих тих посебних испитивања могу сабрати и подредити естетској доминанти испитиваног језичко-уметничког дела, која уједињује његову садржину и форму, те га чини целовитим (исто: 159).

Становиште слично Велековом и Вореновом заузима и Александар Илић у закључку свог рада о структурализму Мукаржовског, мада критикује њихову „поделу на спољашњи и унутрашњи приступ“ у „проучавању књижевности и уметности“, допуштајући је само као методолошку, те захтевајући да „свако целовито“ изучавање дела из ових области хумане активности „представља спој естетичко-значењске анализе“ (исто: 176). По Илићевом мишљењу, уколико се

естетски идентитет, аутономија и квалитет естетске структуре уважавају, приступи књижевно/уметничком делу са аспекта свих оних вредности које су у њему у датом случају присутне јесу легитимни (исто).

Утолико је „сваки естетичко-значењски приступ тумачењу дела одговарајући у оној мери у којој је примерен вредностима и значењима која се у делу појављују“ (исто).

Напротив, песничка творевина је у сваком свом сегменту естетски исход узајамног дејства свих својих чинилаца, тако да се и при њиховом засебном истраживању мора поћи од утиска 
њиховог укупног истовременог узајамног деловања, од импресије поетскоестетске целовитости. Уметнички вредно књижевно дело нам се намеће управо првим утиском песнички вредне целине, наиме тиме да оно завређује барем још једно читање, односно вишекратна читања - ради поновљеног уживања у почетној поетској импресији. Сваким следећим читањем критички се све више осведочавамо по мерилима поетске аксиологије у артистичку вредност целине књижевног дела на основу анализе његових делова као естетскофункционалних за њу, тако да тек од ње они добијају властити уметнички значај и смисао. Утолико су парцијална истраживања различитих, неуметничких вредности језичко-уметничког дела методолошки исправна само за посебне хуманистичке науке које притом примењују своје методе на феномене које деле са књижевношћу.

\section{Бекманова историја форме и Милошевићева филозофија диференције}

Насупрот структуралној критици и науци о књижевности Паул Бекман је пред крај четрдесетих година двадесетог века објавио своје схватање песничких облика (Böckmann, Paul: Die Formgeschichte der deutschen Dichtung, Bd. 1, Hamburg 1949), које је било утемељено на духовноповесном развоју човекове самосвести мимо формалистичко-структуралистичке историјске дијалектике старог и новог, која није могла да образложи суштинску вредност новине, осим таутолошки да је она нешто ново што разбија аутоматизоване, у том тренутку већ квазиартистички овештале шаблоне, који немају више никаквог естетског дејства. Наравно, ова дијалектичка механика је била пука пројекција позитивистичке психологије у раван естетских феномена чије дејство за разлику од других дејстава на људску психу није подложно аутоматизацији, него је вечно делотворно. На једном досегнуту и изражену уметничку лепоту се напросто не може огуглати. Она је вечна естетска вредност коју управо као такву увек изнова преиспитујемо са становишта пријемљивости за њу. А свако такво позиционирање је сваки пут поново производ укупног претходног хуманог развоја, читаве историје људског самоосвешћивања које се најнапредније извршава уметничким облицима као сасвим конкретним и савршено диференцираним, најистанчанијим уобличењима човекове самосвести.

Бекман је у свом схватању формалне историје немачког песништва „песничку форму“ поимао као „историјски променљив 
облик специфичног човековог схватања самога себе“ (Лома 2014: 156), дакле, самим тим она је за њега била незамислива као лишена значења и као безидејна. Утолико би свако људско уобличење морало имати своје значење, свако би морало бити знак неког људског смисла. У том универзалном хуманом поретку знакова песнички облици и знаци заузимају владајуће место, са којег потиче укупна хијерархизација свих човекових знаковних светова и њихових узајамних односа, будући да је за човека најважније од свих његових означења оно песничко, јер ексклузивно представља врхунско човеково саморазумевање под датим околностима његовог простора и времена, односно најмоћније самоспознање и просторно, и временски сасвим конкретне, индивидуалне и оригиналне људскости. Облици песништва су „историјски променљиви“ управо по мери узајамне изражајне прилагођености означенога и знака, променљивог просторновременског скупа хуманих чинилаца који испуњава садржину поетског дела - и уобличења које тој садржини сасвим одговара како би је потпуно и истанчано изразило, те управо тиме је унело у људску самосвест као нову људску вредност, која је стечена уметнички индивидуалним, а људски најдубљим и најопсежнијим искуством.

Да је песнички језик „прецизнији и одређенији“ од сваког прозног исказа закључио је Никола Милошевић на основу свог литерарнокритичког поступка, који - сходно Милошевићевом именовању властите филозофије „диференцијалном“, односно „филозофијом диференције“ - називам „диференцијалном анализом“. Наиме, такво анализирање је „усмерено на утврђивање најтананијих разлика између сличних духовних искустава, те је његов приступ најприлагођенији истраживању индивидуалности, субјективности и персоналности“, а нарочито таквих које су „естетски конкретизоване“, чиме се такав поступак супротставља успостављању универзалних структура на основу утврђених сличности у духовним испољењима. Једино песнички начин изражавања, по Милошевићу, у највишој могућој мери, „у пуноћи својственог интелектуално-емотивног значења“ одговара „сложености и тананости“ човековог доживљаја властитог спољашњег и унутрашњег света (Лома 2014: 145-146).

„Користећи се у својим огледима гносеолошким логичким поступцима, као и онима естетике израза и психологије знања“, Милошевићева

функционална и диференцијална анализа поетске структуре успева да у песничком делу препозна његову темељну филозофску димензију као остварење филозофије диференције, која је не- 
исказива у неком другом медијуму хумане комуникације у својој фундаменталној тежњи ка крајње диференцираном спознању, ка истанчаности у разликовању и поимању интелектуално-емотивних индивидуалности и персоналности. Утолико је Милошевићева диференцијална филозофија као индивидуалистичка филозофија финесе могла достићи властито самопотврђење пре свега применом себи адекватних, диференцијално- и функционално-аналитичких поступака на језичко-уметничка дела, будући да су она већ сама по себи - по својој особеној разлици од свега другог - „језичко уточиште“ за „често необично сложене и танане доживљаје“, тј. за „интелектуално-емотивне садржаје какве је иначе прозним казивањем готово немогуће саопштити“ (Лома 2014: 148-149).

Паул Бекман је сматрао да је „песништво, 'као и свака уметност, значајно за човека' само зато што му 'ставља на располагање формални језик' на коме се он учи да разумева самога себе“. Уметничке форме су „те које 'свим садржајима', односно 'свим доживљајима и искуствима' дају значење“ (Лома 2014: 156). Како је човеково историјско искуство пре свега индивидуално и променљиво, тако се мења и њему изражајно прилагођава и књижевна форма човековог саморазумевања. Утолико „историјски променљиви егзистенцијални садржаји добијају тек кроз адекватно променљиву уметничку форму своје право људско значење“. По Бекману песничко спознање је на специфичан начин естетско. Наиме, њиме се сазнају „различити аспекти људскости у њиховој чулној конкретности“. Тај сазнајни процес се одвија посредством естетски конкретних језичко-уметничких форми, које се уобличавају адекватно променљивим садржајима човекове индивидуалне и историјске егзистенције, како би те садржаје у свим њиховим менама могле изразити. Формалноестетска конкретизација егзистенцијалног смисла човековог појединачног историјског искуства протиче мимо тока појмовног сазнавања, односно мимо сваког његовог уопштавања до појма управо таквих људских индивидуалних садржаја који у својим главним, диференцијалним карактеристикама нису сводљиви на појам (исто: 157).

Тако је песничка форма у Бекмановом књижевнотеоријском и књижевноисторијском разматрању схваћена не само као „носилац естетске“, него „и специфичне гносеолошке вредности“, будући да је „дух 'опажљив' тек кроз форме песничког приказивања“, те је само преко њих „могуће успоставити везу са општијим гносеолошким категоријама духовне историје“. Песнички облици код Бекмана постају аутономни, самостални и самосвојни носио- 
ци смисла који имају „властиту смисаону традицију, односно сопствену историју смисаоних промена“, ношену унутрашњим законитостима њихових естетских мена (исто: 156).

Бекманово виђење естетско-гносеолошког идентитета засновано је на његовом поимању хуманог и естетског феномена као историјских индивидуалности, које се само на основу „доживљаја свиђања“ могу уједно разумевати „као хумано-естетска подударност". Наиме, различити садржаји човековог индивидуалног историјског искуства захтевају себи одговарајуће смисаотворно уобличење, те „имају за човека различит смисао“. Кроз све тако сазнајно-уметнички уобличене и осмишљене садржаје људског појединачног постојања - човек „упознаје и осваја по неку априорну страну своје људскости“, на чему се пак „заснива 'величина и надвременост' песничког деловања“. Бекман је „схватао човека као својствену и непоновљиву историјску егзистенцију“, која се увек збива у „особеној противречности између физичке нужности људског живота и духовне слободе“ егзистенцијалног самоодређења, а које је „спознатљиво једино кроз адекватно конкретну уметничку форму“ (исто: 157). Специфични смисао тог артистичког облика личног саморазумевања ствара се кроз „слободну дијалектику“, односно естетску игру „једног индивидуалног искуства са затеченим смислом“ образовне традиције, чему је исход особена модификација ове (исто: 158). Утолико се општеобразовна, духовна историја у свом уметничком току одвија као права историја кроз сталне сасвим конкретне индивидуалне преображаје обликотворне маште. Њени увек изнова својствено модификовани облици изражавају увек лични смисао човекове судбине, при чему „свака 'животна црта' као 'формални елемент' ове фантазијске форме“ мора бити „функционално уклопљена“ у њу. За Бекмана је неестетско „исто што и нефункционално“ унутар формиране „смисаоне целине“ (исто: 159).

\section{Перманентна структурална дијалектика}

Наспрам главних термина руских формалиста, као што су то „форма“ и „формализам“, примећује Рене Велек да су Јан Мукаржовски, „несумњиво најпродуктивнији чешки учесник“ „Прашког лингвистичког круга“, те и други чланови овога - радије користили термине „структура“ и „структурализам“, како би „избегли уобичајену импликацију празног формализма“. „Када је Мукаржовски дефинисао структуру, истицао ју је како с обзиром 
на спољашњу форму, тако и на такве термине какви су тоталитет, целовитост, Ganzheit или Gestalt“. По Велековом мишљењу, „појам структуре“ се код Мукаржовског „заснива на извесном унутрашњем сједињењу у целину посредством узајамних односа њених делова: и то не само посредством позитивних релација, сагласности и хармоније, него такође и посредством контрадикције и конфликта“. Велек тврди да је ово „дијалектичка концепција, док су руски формалисти, барем у почетку, били помало наивни техничари, емпиристи са јаким механичким тенденцијама“ (Wellek 1970: 275, 276, 278-279).

Међутим та дијалектика може бити естетски функционална само при настанку уметничког облика, док његово целовито уобличење - управо сходно својој целисходности - функционише органски, а не више дијалектички. Перманентна дијалектика слојева и њихових чинилаца у артефакту довела би до његове експлозије, распрскавања и распарчавања какво је иначе могуће само у некритичкој рецепцији која себе кроз такву деконструкцију доживљава као стваралачку иновацију. Такав пријем је могло подстаћи и код Мукаржовског наслеђено формалистичко инсистирање на новини као начелу уметничкоисторијске динамике. Свакако да се критичко примање неког уметничког дела историјски мења, али таквим променама које не раскидају повезаност са његовим ранијим пријемима, будући да сви они, уколико су заиста критички, своје полазиште налазе у чврстој статици изворног целовитог уобличења дела и у његовом првобитном смислу, у његовом чврстом слову, трудећи се да у богатству уобличених хуманих вредности, које свако велико уметничко дело доноси - пронађу до њих незапажене обликотворне црте и да докуче њихово значење у сагласности са већ разоткривеним темељним смислом дела, смислом који је од целине делотворног облика неодвојив. Ако се статички домет његове динамичне обликотворности и смисаотворности уважава, онда уметничка критика доживљава артефакт уједно и као документ његове дијалектичке самоизградње, његовог самоуобличења, и као вечити монумент његове коначне и целовите уобличености, његове трајне стабилизације у довршеном и савршеном облику и њиме уобличеном и откривеном хуманом смислу, као величанствени споменик трајног учвршћивања у поретку вечитих хуманих вредности. Управо дестабилизација структуре у монументалним уметничким делима омогућава релативизацију традиционалног канона хуманости, те отвара пут ка дехуманизујућим проналасцима „новога човека“, који сасвим раскида са претходним хуманистичким традицијама. Та- 
квом новоствореном људском бићу су ради тоталне прагматичке манипулације тежиле тоталитаристичке идеологије и на њима насиљем засновани државни пореци, које је у свом поражавајућем искуству упознао двадесети век, а и сам Мукаржовски на својој властитој судбини.

Александар Илић наводи Велеков увид у недостатке руске формалистичке концепције књижевности и књижевне историје коју је Мукаржовски преузео и у основи сачувао у свом структуралистичком приступу уметничким појавама. Велек је притом истакао да револуционарно напуштање континуиране традиције хуманистичких и уметничких вредности води ка „дехуманизацији уметности и уништењу критике“, која тако губи хумана уметничка мерила, узимајући у обзир само „новину као једино мерило вредности у историјском процесу“ (Илић 2010: 137-138, 140-141). Перманентну револуционарну дијалектику старог и новог Мукаржовски је преузео од руских формалиста и под утицајем чешких критичара марксистичке провенијенције постепено преносио са динамике литерарноформалних односа на динамику друштвених релација, на шта је посебно указао Александар Илић. Перманентна дијалектика коју је Мукаржовски грешком задржао у свом структуралистичком систему мишљења дестабилизовала је сваку мисаону структуру, те релативизовала свако критичко откриће уметничког поретка, који је тако постао протејски, односно само привремено одредив сходно тренутачном критичком увиду, зависном од његове историјске и социјалне позиције. Иста та перманентна дијалектика је Мукаржовском омогућила преображење у марксистичког „новог човека“ и оспособила га за деструкцију традиционалне универзитетске праксе. Наиме, као ректор Карловог универзитета у Прагу почетком педесетих година двадесетог века Мукаржовски сноси одговорност за уништавање тамошњег „труста мозгова“ (исто: 174), доживљеног са становишта ондашње стаљинистичке тоталитарне власти као реметилачког, те непожељног чиниоца јавног живота.

Илић наводи Велеков закључак да „дело Мукаржовског стоји и пада са радовима пре 1948. године“, те да је тај темељни део књижевнонаучног делања Мукаржовског „једна изврсно промишљена кохерентна шема књижевне теорије, која нас у својим најбољим формулацијама штити од главних заблуда ширених у историји“. Међутим, перманентна дијалектика свих релација у оквиру проматраних структура (исто: 170-171) била је деструктивни елемент и грешка у системском решењу, која је напокон тај систем и разградила. Велек је пет година пре смрти Мукаржовског (1975) позитивно оценио главни опус Мукаржовског, а његово потоње марксистичко изокретање, „његов јавни харакири 
из 1950. године“ као пуки „симптом времена“ (исто: 172). У такво научно самопоништавање спада и чланак Мукаржовског из 1951. године под насловом Прилог критици структурализма у нашој науции о књижевности (исто: 49).

Илић сматра да Велек из своје америчке позиције није имао довољно јасан увид (исто: 178-179) у положај „истакнутих интелектуалаца иза гвоздене завесе“ (исто: 173) која је у другој половини двадесетог века готово непропусно делила свет научних и уметничких, политичких и економских слобода од света комунистичког тоталитаризма. Тако је Велек, по Илићевом мишљењу, „поновно објављивање Естетичких студија Јана Мукаржовског 1966. године“ (исто: 177) „неправедно потценио као 'симптом времена““ (исто: 172). Узимајући у обзир оба историјски симптоматична догађаја, и одрицање од властитог раног дела почетком педесетих година, и његово објављивање након деценију и по, почетком друге половине шездесетих година двадесетог века (исто: 38), Илић тврди да ни један, ни други случај „нису били 'симптоми времена', већ истрајног, мукотрпног, често понижавајућег залагања, праћеног многим компромисима“, да се „уобличи другачија парадигма, конкурентна монотоној хипнози догматског и монополистичког марксизма“ (исто: 173). Штавише, објављивање раних радова Мукаржовског у другој половини шездесетих година двадесетог века је, по Илићу, „у паклу социјализма“ представљало „симптом против времена“ (178-179). Илић, који је живео под комунистичком диктатуром у Југославији, за разлику од Велека који није прошао кроз такво искуство - има „хуманистичко разумевање“ за „положај службених и толерисаних интелектуалаца у стаљинизму, и уопште у комунизму и у тоталитарним режимима“. По његовом мишљењу, „Мукаржовски је био пуко оруђе, лутка у рукама надмоћних и отворено злочиначких сила. Оне су биле покретачи и прави извршиоци зла“ (исто: 173-174).

Схватање Мукаржовског изнето у његовом огледу о „Естетској функцији, норми и вредности као социјалним чињеницама“ да „све компоненте уметничког дела, садржинске и формалне, представљају носиоце ванестетских вредности које у делу ступају“ у узајамне односе - критиковао је Велек тврђењем да по мишљењу Мукаржовског испада како је уметност „само аранжман или комбиновање неуметности“ (исто: 149-150). Илић је увидео да Велекова карактеристика става Мукаржовског погађа како бит радикалног левичарског схватања стваралаштва као деструкције и поновне конструкције од ванестетских елемената, тако и суштину 
авангардистичких уметничких покрета двадесетог века све до постмодерне. Полазећи од тог увида Илић је проширио Велекову критику и на погубно дејство левичарске литерарне авангарде на схватање уметности и њене повести код Мукаржовског (исто: 142, 148-149, 150-152, 153). Но Илић је промену чешког структуралисте у другог, новог човека марксистичког преумљења посматрао као исход изнуде насилничког тоталитарног режима (исто: 168). Деконструкционистичко угрожавање не само књижевних него и хуманистичких студија у целини препознао је код постструктуралиста Велек тек накнадно, под старе дане, критикујући Деридин приступ и његово разорно дејство на ове темељне образовне области (Wellek 1990).

\section{Лumepamypa}

Илић, А. (1998). Поговор. Мукаржовски, Ј., Огледи из естетике и поетике. Београд: Завод за уџбенике и наставна средства. 215-221.

Лома, М. (1994). Песник и књижевна историја, Проблем приказивања песника у историјама немачке књижевности. Нови Сад: Издавачка књижарница Зорана Стојановића Сремски Карловци.

Лома, М. (2014). Тумачење поеме Стражилово Милоша Црњанског и књижевнокритички поступак Николе Милошевића. Глас CDXXI Српске академије наука и уметности, Одељење језика и књижевности, 29, 131-153.

Лома, М. (2019). Александар Илић (1945-2018), Илићево завештање слободе. Филолошки преглед, 2, 167-190.

Ilić, A. (2010). Od forme do strukture: ruski formalizam / češki strukturalizam. Beograd: Interprint.

Mukaržovski, J. (1986). Struktura, funkcija, znak, vrednost, Ogledi iz estetike i poetike. Beograd: Nolit.

Schiller, F. (1955). Schiller, Werke in drei Bänden, Bd. 2: Die mittlere Epoche 1787-1798: Verwandlung, Leipzig: VEB Bibliographisches Institut.

Wellek, R. (1970). Discriminations, Further Concepts of Criticism. New Haven and London: Yale University Press.

Wellek, R. / Warren, A. (1985). Theory of Literature, A seminal study of the nature and function of literature in all its contexts. Prescott, (Arizona, USA): Peregrine Books.

Wellek, R. (1990). Destroying Literary Studies. Metodološka misao u preseku: sadašnji trenutak nauke o književnosti: Zoranu Konstantinoviću. Beograd: Godišnjak Instituta za književnost i umetnost, 25-34. 


\title{
Miodrag Loma
}

Universität Belgrad, Philologische Fakultät

\section{Aleksandar Ilić und Strukturalismus von Jan Mukařovský}

\author{
- Zusammenfassung -
}

In der vorliegenden Arbeit wird das kritische Verfahren dargestellt und bewertet, mit dem Aleksandar Ilić (1945-2018), Ordinarius am Lehrstuhl für Weltliteratur und Literaturtheorie an der Philologischen Fakultät der Universität Belgrad, sich Zugang zum Verständnis des Entwicklungsweges der strukturalistischen Lehre im Werk von Jan Mukařovský (1891-1975) verschaffte, einem Professor an der Karl-Universität Prag. Ilić ging dabei von zwei komplementären Standpunkten aus, deren einer die kritische Analyse war, der René Wellek (1903-1995), Professor an der Yale-University und ehemaliges Mitglied des Prager Linguistenkreises, in dem Mukařovský eine der führenden Rollen spielte, den russischen Formalismus und den tschechischen Strukturalismus unterworfen hatte. Den anderen, ergänzenden Standpunkt zur Bewertung der strukturalistischen Theorie und ihrer Interpretationspraxis in Mukařovskýs Werk entnahm Ilić den philosophischen Studien seines Lehrers, Vorgängers und später auch Kollegen an demselben Lehrstuhl Nikola Milošević (1929-2007), der zur Folgerung kam, dass bei der Entstehung eines sprachkünstlerischen Werks klar zwischen den „Bedingungen“ und den „Ursachen“ zu unterscheiden sei; die beiden seien außerästhetische Faktoren, wobei die ersteren zur ganzheitlichen künstlerischen Gestaltung beitrügen, indem sie sich der ästhetischen Intention des Künstlers funktionell unterwürfen, während sich die letzteren dem Vorhaben entgegensetzten und es behinderten, sodass sie auf die künstlerische Konstitution des Werks zerstörend wirken sollen. Damit vermag Milošević die strukturalistische Aporie der gegenseitigen Beziehungen von ästhetischen und außerästhetischen Funktionen in einem Kunstwerk aufzulösen. Miloševićs „differentielle Analyse“, die einen feinen Unterschied zwischen den Einflüssen der gestaltenden und den Einwirkungen der verunstaltenden Kräfte auf die Entstehung eines Sprachkunstwerks macht, ließe sich hier mit den formalund geistesgeschichtlichen Betrachtungen Paul Böckmanns (1899-1987) ergänzen, eines Professors an der Heidelberger und Kölner Universität, der in den künstlerischen Gestaltungen ganz konkrete und bedeutungsvollste Formen der menschlichen Selbstauffassung sah. Schließlich wird auf die permanente strukturelle Dialektik im Denken Mukařovskýs als destabilisierenden Faktor für eine grundlegende Feststellung der Textform und ihrer Bedeutung beziehungsweise des ästhetischen Erlebnisses und seiner Deutung hingewiesen.

Schlüsselwörter: Aleksandar Ilić, Jan Mukařovský, René Wellek, Nikola Milošević, Paul Böckmann; Formalismus, Strukturalismus, Differenzphilosophie und differentielle Analyse, Geistesgeschichte, Formgeschichte, permanente Dialektik, Marxismus, Dekonstruktion. 